\title{
The Role of Knowledge Management in Enhancing Customer Experience Management - Field study: Private Hospitals in Amman, Jordan
}

\author{
Manar Reyad Maraqa \\ $\mathrm{PhD}$, Department of Management Information Systems \\ Al-Balqa Applied University \\ Amman, Jordan
}

\begin{abstract}
This study seeks to explore the impact of knowledge management processes (KMPs) (knowledge creation, acquisition, storing, sharing and implementation) on customer experience management. Descriptive, analytical approach was used in this study; data were collected through questionnaires that were physically distributed to a random sample of 215 respondents. They constituted of marketing directors and workers in private hospitals in Amman, Jordan. The model achieves an acceptable fit and was found that knowledge management processes explain $88.88 \%$ of the variance in customer experience management. Linear and multiple regression analysis were both used to examine the research hypotheses using SPSS. The outcomes of the study showed that KMPs have a clear impact on customer experience management. Knowledge sharing specifically has the highest impact on customer experience management while knowledge implementation has the least impact. Consequently, the study recommends establishing a specialised department concerned with managing knowledge processes in an organised and informed manner in private hospitals. In addition, the study recommends holding workshops on information security and privacy to acquaint workers with the concept of data and information security and its legal and ethical aspects that are related to misuse of data sources in the hospital. Lastly, the study further advices directing, encouraging and supporting workers in implementing the knowledge they gained, which benefits employees and the work environment in the hospital in general.
\end{abstract}

\section{General Terms}

Knowledge Management, Customer Experience Management.

\section{Keywords}

Knowledge management processes, knowledge creation, knowledge acquisition, knowledge storing, knowledge sharing, knowledge implementation, customer experience management, private hospitals, Jordan.

\section{INTRODUCTION}

Health services in Jordan are provided by the institutions of three sectors: public, private and international. Institutions of the public sector include the Ministry of Health, royal medical services, public universities' hospitals, and the National Centre for Diabetes Endocrinology and Genetics. The private sector provides primary, secondary and tertiary health care services through hospitals, medical centers and clinics. Health services of the international and charity sector are provided through the UNRWA, King Hussein Cancer Centre, Jordan Red Crescent Society and a number of charity organisations that provide primary health care services only [1]. The
Jordanian health sector is known regionally and internationally for its level of excellence, which makes it a significant revenue source for the domestic economy due to the key health tourism activities in the country. According to [2], Jordan is the number one Arab country and among the top ten countries in the field of health tourism. This is attributed to a number of reasons including the quality of medical services, the highly qualified health staff specialising in all medical fields, accredited hospitals equipped with state-ofthe-art medical devices and equipment which reduces the waiting time to receive the service, and finally the political stability and security in Jordan compared to other countries in the region [2]. Private sector hospitals are considered the major player in the health tourism sector. A 2012 survey revealed that a quarter million patients from around the globe received medical services in Jordanian private hospitals; this constitutes $23 \%$ of the total patients receiving such services in Jordan [2]. These hospitals took major steps towards achieving the highest level of patients' satisfaction by participating in accreditation, excellence and ISO programs that help improve and increase the efficiency of their services. The previous data confirms the importance of this sector as part of this study given its vitality and direct contact and involvement with health care recipients. In this sector, client relations management and the experience patients go through when dealing with such health institutions are both keys to its success. The study was conducted in Amman being the largest city and the heart of the medical sector in Jordan as there are 65 private hospitals in Jordan, 43 of them are located in Amman [1]. While clients' experience is given significant attention at the practical level, it has not been tackled thoroughly in literature. This type of experience has been seen as part of the customer knowledge within an organisation rather a separate element by itself. And although many studies investigated knowledge management and its practices, impact on performance, increasing competitivity, innovation, CRM success and others, there has not been enough research on knowledge management role in improving customer experience management in the service industry. To fill this gap, this study seeks to explore the impact of knowledge management on improving customer experience management in the healthcare sector, especially in private hospitals in Amman, Jordan. The results of this study are expected to help decision-makers in private hospitals identify opportunities that may increase the amount of investment in this sector, and consequently increasing the national income. 


\section{LITERATURE REVIEW}

\subsection{Knowledge Management and Its \\ Processes}

Expertise, skills, information, education, facts and other elements constitute the collection of knowledge that people and organisations own [3]. Knowledge was also defined as the collection of data that is generated, organised, and recapitulated for the purpose of improving skills and understanding [4]. The ways to store knowledge have been countless over time. Some knowledge is stored in the minds of individuals others are documented in the form of policies, procedures, instructions etc. This knowledge is also shared in different ways in conversations, training, apprenticeship programs and reports. Knowledge is growing in importance everyday and researchers such as Sujatha and Krishnaveni [5] believe that this renewed interest in knowledge stems from the fact of it being a resource that requires management in the context of organisations. Organisational knowledge is seen by [6] as an imperceptible treasure and a key source to improve and expand an organisation as it allows promoting an organisation's quantity and quality indicators. Therefore, it is important that organisations manage their knowledge using formal tailor-made processes and actions; a concept known as knowledge management (KM). When described in action, knowledge management is the process of capturing the collective experience of an organisation in its various forms. As this experience is captured it is stored electronically, physically or intellectually and shared in the manner that achieves maximum benefit [7]. A definition of KM given by [8] says that it is a series of procedures that uses methods and tools to make knowledge accessible when needed for problem solving or decision making. For an organisation, KM may be defined as a set of organisational processes that seek to generate, maintain, share and apply knowledge [9]. Previous studies tackling this topic did not come to a unified concept of KM processes (KMPs). Therefore, for the study in hand, the researcher identifies with [10] and [11] to specify five main processes for KM: the creation of knowledge, acquiring it, storing it into a system, followed by sharing and using the knowledge among concerned parties. Below is a definition of each of these processes

Knowledge creation is the use of internal and external information sources to generate knowledge that serves an organisation's objective [10]. Knowledge acquisition is the next step where information is specifically selected and added to relevant knowledge within the organisation. This step requires a proper set of tools, such as people, information technology, libraries, books, multimedia etc., to facilitate access to the needed knowledge. These tools are essential for the success of the knowledge acquisition phase [12]. As for the knowledge storage it is defined as the process of maintaining the acquired knowledge using different methods [13]. One of these methods is organised and categorised documents to facilitate access to knowledge [13]. However, knowledge possessed by the individual alone or by the organisation as a whole can be kept electronically as well as physically for it to be easily retrieved [10]. The next process is the knowledge sharing which is defined as the transfer of knowledge among individuals [14] and as a "social interaction culture, involving the exchange of employee knowledge, experiences, and skills through the whole department or organisation" [15]. This process was described by [16] as the pillar of $\mathrm{KM}$ in organisations and as a key element for companies to gain a competitive advantage. Knowledge sharing serves the purpose of using it to create a valuable asset for the benefit of an organisation [17]

The final process is knowledge implementation where knowledge is applied for decision-making, improving performance and attaining objectives [10]. The processes of identifying, collecting, attaining, storing and sharing knowledge help organisations and companies apply this knowledge to solve problems and create strategies that increase the company's efficiency and effectiveness.

\subsection{Customer Experience Management}

Seligman [18] described the concept of customer experience as the set of feelings and mental images that a company leaves in a customer after an episode of contact or communication between the two to sell a product or provide service or support. The success of this experience is often resembled when a customer buys the product or uses the provided service. Hashem et al. [19] cited [20] and [21] noting that customer experience has three elements: sensory, emotional, and social. Customers' observations about the worth and visual attributes of a product or a service is what makes the sensory part of this experience. The emotional element includes the feelings attributed to buying the product or receiving the service. And the social element here means the form of social interactions that the customer experiences as a result of this product or service. Delivering the company's promises is what creates customer experience. This happens at the moment of interaction between the company and the customer. For this reason, CEM is reflected by the sales people, the customer care officers, the ads, the activities carried out by the company, the leaflets, the website, etc. The experience of the customer is formed by his or her expectations from a certain brand, and this is many times attained by the public reputation of the brand or company and the opinions of its other clients [22]. According to [23], customer relationship management (CRM) can be enhanced by the use of KM as it allows an organisation to improve its services and customer support.

This study seeks to prove that KM has a key influence on CEM. The documentation of knowledge, for example, assists employees in the process of resolving issues in a swift manner without the customer noticing the problem. Furthermore, lessons learnt help employees identify the issues they may face and choose the way to solve and improve their service delivery. Having this knowledge stored saves new staff members the effort of reinventing the wheel whenever a problem occurs [24]. The importance of KM for customer experience will be illustrated by the empirical study in this research through answering the study question and testing the hypotheses.

\section{THE STUDY QUESTION AND HYPOTHESES}

The study's problem can be illustrated in the following question: what impact do knowledge management processes have on customer experience management in private hospitals in Amman, Jordan?

Also based on the previous literature the following hypotheses are formulated:

H0: There is no statistically significant impact at $(\alpha \leq 0.05)$ of knowledge management processes on customer experience management in private hospitals in Amman, Jordan.

And the following sub-hypotheses were deduced from the main hypothesis above: 
H0-1: There is no statistically significant impact at $(\alpha \leq 0.05)$ of knowledge creation on customer experience management in private hospitals in Amman, Jordan.

H0-2: There is no statistically significant impact at $(\alpha \leq 0.05)$ of knowledge acquisition on customer experience management in private hospitals in Amman, Jordan.

H0-3: There is no statistically significant impact at $(\alpha \leq 0.05)$ of knowledge storing on customer experience management in private hospitals in Amman, Jordan.

H0-4: There is no statistically significant impact at $(\alpha \leq 0.05)$ of knowledge sharing on customer experience management in private hospitals in Amman, Jordan.

H0-5: There is no statistically significant impact at $(\alpha \leq 0.05)$ of knowledge implementation on customer experience management in private hospitals in Amman, Jordan.

\section{STUDY METHODS}

\subsection{Methodology}

This study uses a descriptive, analytical approach. Periodicals, books, and electronic articles were the references adopted for the theoretical framework of this study, on the one hand. For field work, on the other hand, a questionnaire was to collect the required data.

\subsection{Statistical Treatment Methods}

SPSS v21 software was the tool used for questionnaire data analysis. Statistical methods used were: frequencies and percentages, means and standard deviations, linear and the multiple regression analysis. The followings through this section explain the analysis of the collected data.

\subsection{Questionnaire Design}

After reviewing previous studies investigating the same topic, a questionnaire was created to be the study tool. It primarily consisted of 34 items, 23 of them measure the independent variable (knowledge management processes) in five dimensions and 11 measure the dependent variable (customer experience management). The research questionnaire was divided into two parts. The first collected users' demographic data (gender, age, education, occupation, and experience), while the other asked questions concerning the recognition of variables. A 5-degrees Likert scale was used: (5) points strongly agree, (4) points agree, (3) moderately agree, (2) points disagree, (1) point strongly disagrees.

\subsection{Reliability Test}

To ascertain instrument reliability, a Cronbach Alpha test was used and the coefficient value was 0.905 for the questionnaire. All values are accepted since they are more than 0.60 (Malhotra, 2004).

\subsection{Study Validity}

The validity of the study, in its initial form, was presented for check to 7 expert and experienced trustees from Jordanian universities. Afterwards, the tools based modified based on the trustees' feedback and recommendations. The modifications concerned linguistic formation of some items.

\subsection{Population and Sampling}

The study population consists of all workers in the field of marketing in private hospitals in Amman, Jordan. According to the statistics of the Jordanian Ministry of Health [1], there are 43 private hospitals in Amman. A sample of 215 persons was chosen and the questionnaire was distributed among them
(5 questionnaires for each hospital). 172 questionnaires were returned, $80 \%$ of all questionnaires. Frequency and percentages have been computed for the sample's characteristics as shown in Table 1.

Table 1. Sample's Distribution According to Demographic Information

\begin{tabular}{|c|c|c|}
\hline Category & Frequency & Percentage \% \\
\hline \multicolumn{3}{|c|}{ Gender } \\
\hline Male & 111 & 64.5 \\
\hline Female & 61 & 35.5 \\
\hline Total & 172 & $100 \%$ \\
\hline \multicolumn{3}{|c|}{ Age } \\
\hline Less than 30 years & 59 & 34.3 \\
\hline $\begin{array}{c}\text { 30- Less than } 40 \\
\text { years }\end{array}$ & 29 & 16.9 \\
\hline $\begin{array}{c}\text { 40- Less than } 50 \\
\text { years }\end{array}$ & 44 & 25.6 \\
\hline 50 years + & 40 & 23.3 \\
\hline Total & 172 & $100.0 \%$ \\
\hline \multicolumn{3}{|c|}{ Education } \\
\hline Diploma or less & 28 & 16.3 \\
\hline Bachelor's degree & 106 & 61.6 \\
\hline Higher degrees & 38 & 22.1 \\
\hline Total & 172 & $100 \%$ \\
\hline \multicolumn{3}{|c|}{ Occupation } \\
\hline $\begin{array}{c}\text { Administrative } \\
\text { Director }\end{array}$ & 13 & 7.6 \\
\hline Head of Department & 27 & 15.7 \\
\hline Head of Section & 35 & 20.3 \\
\hline Employee & 97 & 56.4 \\
\hline Total & 172 & $100.0 \%$ \\
\hline \multicolumn{3}{|c|}{ Experience } \\
\hline Less than 5 years & 54 & 31.4 \\
\hline $\begin{array}{c}5 \text { - Less than } 15 \\
\text { years }\end{array}$ & 38 & 22.1 \\
\hline $\begin{array}{c}15 \text {-Less than } 25 \\
\text { years }\end{array}$ & 33 & 19.2 \\
\hline 25 years + & 47 & 27.3 \\
\hline Total & 172 & $100.0 \%$ \\
\hline
\end{tabular}

From the above table, it is illustrated that $64.5 \%$ of the sample are males, the rest are females. Also $16.3 \%$ of the sample has a diploma or less, $61.6 \%$ of the sample has bachelor degree, and the rest have higher degrees. Also, it shows that experience of less than 5 years is $(31.4 \%)$. (5- Less than 15 years) is $(22.1 \%)$, (15-Less than 25 years) is (19.2\%) and above 25 years is $(27.3 \%)$ percent. As for the occupation; $7.6 \%$ of the sample was administrative director. $15.7 \%$ were head of department, $20.3 \%$ were head of section, and the rest were employees. Finally, it is found that the highest percent of the sample $(51.2 \%)$ is less than 40 years old. 


\section{ANALYSIS AND DISCUSSION}

\subsection{Descriptive Analysis}

Table 2. Attitudes toward the Study Variables

\begin{tabular}{|c|c|c|}
\hline & Mean & Std. Deviation \\
\hline Knowledge Creation & 3.4651 & .76039 \\
Knowledge Acquisition & 3.4512 & .70067 \\
Knowledge Storing & 3.7108 & .74652 \\
Knowledge Sharing & 3.5558 & .74764 \\
Knowledge Implementation & 3.5581 & .84611 \\
Customer Experience Management & 3.6549 & .65607 \\
\hline
\end{tabular}

Table 2 indicates that there are positive attitudes toward the above variables because their means are above the mean of the scale (3). It is found that knowledge storing has the highest positive attitudes followed by customer experience management.

\subsection{Hypotheses Testing}

To test the main hypothesis, multiple regression analysis was used to test the impact of knowledge management processes on customer experience management.

H0: There is no statistically significant impact at $(\alpha \leq 0.05)$ of knowledge management processes on customer experience management in private hospitals in Amman, Jordan.

Table 3. Test of H0- Model Summary

\begin{tabular}{|c|c|c|c|c|}
\hline Model & $\mathbf{R}$ & R Square & $\begin{array}{c}\text { Adjusted R } \\
\text { Square }\end{array}$ & $\begin{array}{c}\text { Std. Error of the } \\
\text { Estimate }\end{array}$ \\
\hline 1 & $.943^{\mathrm{a}}$ & .8888 & .885 & .22240 \\
\hline
\end{tabular}

Table 3 shows that $\mathrm{R}$, the correlation coefficient, was calculated at (0.943) and this reflects a strong relationship between the independent variable (knowledge management processes) and the dependent variable (customer experience management). R-square, the coefficient of determination, was equal to (0.8888) according to the table. This displays that knowledge management processes in the method clarify $88.88 \%$ of the variance in the customer experience management. This allows the study's main hypothesis to be tested. The below tables represent the results.

Table 4. ANOVAa table for $\mathrm{HO}$

\begin{tabular}{|cc|c|c|c|c|c|}
\hline Model & $\begin{array}{c}\text { Sum of } \\
\text { Squares }\end{array}$ & df & $\begin{array}{c}\text { Mean } \\
\text { Square }\end{array}$ & F & Sig. \\
\hline \multirow{2}{*}{1} & Regression & 65.391 & 5 & 13.078 & 264.407 & $.000^{\mathrm{b}}$ \\
& Residual & 8.211 & 166 & .049 & & \\
& Total & 73.602 & 171 & & & \\
\hline
\end{tabular}

Table 5. Coefficientsa table for $\mathrm{HO}$

\begin{tabular}{|c|c|c|c|c|c|}
\hline \multirow[t]{2}{*}{ Model } & \multicolumn{2}{|c|}{$\begin{array}{l}\text { Unstandardized } \\
\text { Coefficients }\end{array}$} & \multirow{2}{*}{$\begin{array}{c}\begin{array}{c}\text { Standardized } \\
\text { Coefficients }\end{array} \\
\text { Beta }\end{array}$} & \multirow[t]{2}{*}{$\mathbf{t}$} & \multirow[t]{2}{*}{ Sig. } \\
\hline & B & Std. & & & \\
\hline (Constant) & .192 & .102 & & 1.885 & .061 \\
\hline $\begin{array}{l}\text { Knowledge } \\
\text { Creation }\end{array}$ & -.254 & .045 & -.294 & -5.623 & .000 \\
\hline $\begin{array}{l}\text { Knowledge } \\
\text { Acquisition }\end{array}$ & .092 & .035 & .098 & 2.609 & .010 \\
\hline $\begin{array}{l}\text { Knowledge } \\
\text { Storing }\end{array}$ & .304 & .030 & .345 & 10.032 & .000 \\
\hline $\begin{array}{l}\text { Knowledge } \\
\text { Sharing }\end{array}$ & .618 & .039 & .704 & 15.962 & .000 \\
\hline $\begin{array}{c}\text { Knowledge } \\
\text { Implementatio }\end{array}$ & .197 & .032 & .254 & 6.202 & .000 \\
\hline
\end{tabular}

According to Table 4, the value of F (264.407) was significant at (0.05). This shows a statistically significant impact of knowledge management processes on customer experience management in private hospitals in Amman, Jordan. The values of $t$ in Table 5 for each variable are found to be significant at the level of 0.01 . This says that each variable has an impact on customer experience management.

\section{Next is testing the sub-hypothesis}

H0-1: There is no statistically significant impact at $(\alpha \leq 0.05)$ of knowledge creation on customer experience management in private hospitals in Amman, Jordan.

Table 6. Test of H0-1 Model Summary

\begin{tabular}{|c|c|c|c|c|}
\hline Model & R & R Square & $\begin{array}{c}\text { Adjusted R } \\
\text { Square }\end{array}$ & $\begin{array}{c}\text { Std. Error of } \\
\text { the Estimate }\end{array}$ \\
\hline 1 & $.735^{\mathrm{a}}$ & .540 & .537 & .44645 \\
\hline
\end{tabular}

To test the hypothesis, linear regression method was used. The testing found that the correlation coefficient between knowledge creation and customer experience management $(\mathrm{R})$ was equal to $(0.735)$ as seen in Table 6 . This reveals a strong relationship between the two. The coefficient of determination (R-square) was calculated at (0.540) showing that knowledge creation process in the method clarifies $54 \%$ of the variance in the customer experience management. Hence, the study's first sub-hypothesis can be tested. Testing outcomes are illustrated in the tables next.

Table 7. ANOVAa table for $\mathrm{H0}-1$

\begin{tabular}{|c|c|c|c|c|c|}
\hline Model & $\begin{array}{c}\text { Sum of } \\
\text { Squares }\end{array}$ & df & $\begin{array}{c}\text { Mean } \\
\text { Square }\end{array}$ & $\mathbf{F}$ & Sig. \\
\hline Regression & 39.718 & 1 & 39.718 & 199.271 & $.000^{\mathrm{b}}$ \\
\hline 1 Residual & 33.884 & 170 & .199 & & \\
\hline Total & 73.602 & 171 & & & \\
\hline
\end{tabular}


Table 8. Coefficientsa table for $\mathrm{H0-1}$

\begin{tabular}{|c|c|c|c|c|c|}
\hline Model & \multicolumn{2}{|c|}{$\begin{array}{c}\text { Unstandardized } \\
\text { Coefficients }\end{array}$} & $\begin{array}{c}\text { Standardized } \\
\text { Coefficients }\end{array}$ & \multirow{2}{*}{ Sig. } & \\
\cline { 2 - 4 } & $\mathbf{B}$ & Std. & Beta & & \\
\hline & $\begin{array}{c}\text { (Constant) } \\
1.459\end{array}$ & .159 & & 9.159 & .000 \\
$\begin{array}{c}\text { Knowledge } \\
\text { Creation }\end{array}$ & .634 & .045 & .735 & 14.116 & .000 \\
\hline
\end{tabular}

As shown above, F was calculated at (199.271) and it is found to be significant at level (0.05). Accordingly we find that knowledge creation has a statistically significant impact on customer experience management in Amman's private hospitals.

Testing H0-2: There is no statistically significant impact at ( $\alpha$ $\leq 0.05$ ) of knowledge acquisition on customer experience management in private hospitals in Amman, Jordan.

Table 9. Test Of H0-2 Model Summary

\begin{tabular}{|l|r|r|r|r|}
\hline Model & \multicolumn{1}{|c|}{ R } & R Square & \multicolumn{1}{|c|}{$\begin{array}{c}\text { Adjusted R } \\
\text { Square }\end{array}$} & $\begin{array}{l}\text { Std. Error of } \\
\text { the Estimate }\end{array}$ \\
\hline 1 & $.661^{2}$ & .437 & .434 & .49357 \\
\hline
\end{tabular}

For the testing of this hypothesis, linear regression was used. The outcomes showed that $\mathrm{R}$ was equal to $(0.661)$ revealing a positive relation between knowledge acquisition and customer experience management. For this hypothesis, R-square was calculated at $(0.437)$. This value reflects that the process of knowledge acquisition clarifies $43.7 \%$ of the variance in customer experience management.

Table 10. ANOVA ${ }^{a}$ table for $\mathrm{HO-2}$

\begin{tabular}{|rl|r|r|r|c|c|}
\hline Model & $\begin{array}{r}\text { Sum of } \\
\text { Squares }\end{array}$ & df & $\begin{array}{r}\text { Mean } \\
\text { Squar }\end{array}$ & F & Sig. \\
\hline \multirow{2}{*}{1} & Regression & 32.188 & 1 & 32.188 & 132.129 & $.000^{\mathrm{b}}$ \\
& Residual & 41.414 & 170 & .244 & & \\
& Total & 73.602 & 171 & & & \\
\hline
\end{tabular}

Table 11. Coefficients ${ }^{\mathrm{a}}$ table for $\mathrm{HO-2}$

\begin{tabular}{|c|c|c|c|c|c|}
\hline \multirow[t]{2}{*}{ Model } & \multicolumn{2}{|c|}{$\begin{array}{l}\text { Unstandardized } \\
\text { Coefficients }\end{array}$} & $\begin{array}{l}\text { Standardized } \\
\text { Coefficients }\end{array}$ & \multirow[t]{2}{*}{$\mathbf{t}$} & \multirow[t]{2}{*}{ Sig. } \\
\hline & B & Std. & Beta & & \\
\hline (Constant) & 1.518 & .190 & & 8.002 & .000 \\
\hline $\begin{array}{l}1 \text { Knowledge } \\
\text { Acquisition }\end{array}$ & 619 & .054 & .661 & 11.495 & .000 \\
\hline
\end{tabular}

Also found is that the value of $\mathrm{F}$ was equal to (132.129) with significance at the level (0.05). This shows that knowledge acquisition has a statistically significant impact on customer experience management in private hospitals in Amman, Jordan.

H0-3: There is no statistically significant impact at $(\alpha \leq 0.05)$ of knowledge storing on customer experience management in private hospitals in Amman, Jordan.
Table 12. Test of H0-3 Model Summary

\begin{tabular}{|c|c|c|c|c|}
\hline Model & R & R Square & $\begin{array}{c}\text { Adjusted R } \\
\text { Square }\end{array}$ & $\begin{array}{c}\text { Std. Error of } \\
\text { the Estimate }\end{array}$ \\
\hline 1 & $.718^{\mathrm{a}}$ & .516 & .513 & .45787 \\
\hline
\end{tabular}

The testing of this hypothesis required using the linear regression method. The outcomes revealed $\mathrm{R}$ at value equal to (0.718), representing the correlation between knowledge storing and customer experience management. It was also found that knowledge storing clarifies $51.6 \%$ of the variance in the customer experience management.

Table 13. ANOVA ${ }^{\mathrm{a}}$ table for $\mathrm{H0-3}$

\begin{tabular}{|cc|c|c|c|c|c|}
\hline Model & $\begin{array}{c}\text { Sum of } \\
\text { Squares }\end{array}$ & df & $\begin{array}{c}\text { Mean } \\
\text { Square }\end{array}$ & F & Sig. \\
\hline \multirow{2}{*}{1} & Regression & 37.962 & 1 & 37.962 & 181.079 & $.000^{\mathrm{b}}$ \\
& Residual & 35.640 & 170 & .210 & & \\
& Total & 73.602 & 171 & & & \\
\hline
\end{tabular}

Table 14. Coefficients ${ }^{\mathrm{a}}$ table for $\mathrm{HO-3}$

\begin{tabular}{|c|c|c|c|c|c|}
\hline \multirow[t]{2}{*}{ Model } & \multicolumn{2}{|c|}{$\begin{array}{c}\text { Unstandardized } \\
\text { Coefficients }\end{array}$} & \multirow{2}{*}{$\begin{array}{c}\begin{array}{c}\text { Standardized } \\
\text { Coefficients }\end{array} \\
\text { Beta }\end{array}$} & \multirow[t]{2}{*}{$\mathbf{t}$} & \multirow[t]{2}{*}{ Sig. } \\
\hline & B & Std. & & & \\
\hline (Constant) & 1.313 & .178 & & 7.395 & .000 \\
\hline $\begin{array}{c}\text { Knowledge } \\
\text { Storing }\end{array}$ & .631 & .047 & .718 & 13.457 & .000 \\
\hline
\end{tabular}

The value of $\mathrm{F}$ in Table 13 was (181.079) with significance at a (0.05) level. We deduce here, that knowledge storing has a statistically significant impact on customer experience management in Amman's private hospitals.

H0-4: There is no statistically significant impact at $(\alpha \leq 0.05)$ of knowledge sharing on customer experience management in private hospitals in Amman, Jordan.

Table 15. Test of H0-4 Model Summary

\begin{tabular}{|l|r|r|r|r|}
\hline Model & \multicolumn{1}{|c|}{ R } & R Square & $\begin{array}{c}\text { Adjusted R } \\
\text { Square }\end{array}$ & $\begin{array}{l}\text { Std. Error of } \\
\text { the Estimate }\end{array}$ \\
\hline 1 & $.863^{\mathrm{a}}$ & .745 & .743 & .33253 \\
\hline
\end{tabular}

Table 16. ANOVA ${ }^{\mathrm{a}}$ table for $\mathrm{HO}-4$

\begin{tabular}{|c|c|c|c|c|c|c|}
\hline Model & $\begin{array}{c}\text { Sum of } \\
\text { Squares }\end{array}$ & df & $\begin{array}{c}\text { Mean } \\
\text { Square }\end{array}$ & F & Sig. \\
\hline & Regression & 54.804 & 1 & 54.804 & 495.623 & $.000^{\mathrm{b}}$ \\
1 & Residual & 18.798 & 170 & .111 & & \\
& Total & 73.602 & 171 & & & \\
\hline
\end{tabular}


Table 17. Coefficients ${ }^{\mathrm{a}}$ table for $\mathrm{H0-4}$

\begin{tabular}{|c|c|c|c|c|c|}
\hline \multirow{2}{*}{ Model } & \multicolumn{2}{|c|}{$\begin{array}{c}\text { Unstandardized } \\
\text { Coefficients }\end{array}$} & $\begin{array}{c}\text { Standardized } \\
\text { Coefficients }\end{array}$ & \multirow{2}{*}{ Sig. } \\
\cline { 2 - 4 } & $\mathbf{B}$ & Std. & Beta & & \\
\hline \multirow{2}{*}{1 (Constant) } & .962 & .124 & & 7.788 & .000 \\
$\begin{array}{c}\text { Knowledge } \\
\text { Sharing }\end{array}$ & .757 & .034 & .863 & 22.263 & .000 \\
\hline
\end{tabular}

Linear regression method was also used here to test this hypothesis. For this part, $\mathrm{R}$ was found to be equal to (0.863) as the correlation value between knowledge sharing and customer experience management. This is strong and positive relation between the two variables. The testing calculated the value of $F$ to be (495.623) with significance at (0.05). This reveals a statistically significant influence of knowledge sharing on customer experience management in the private hospitals of Amman.

Finally testing H0-5: There is no statistically significant impact at $(\alpha \leq 0.05)$ of knowledge implementation on customer experience management in private hospitals in Amman, Jordan

Table 18. Test of H0-5 Model Summary

\begin{tabular}{|c|c|c|c|c|}
\hline Model & R & R Square & $\begin{array}{c}\text { Adjusted R } \\
\text { Square }\end{array}$ & $\begin{array}{c}\text { Std. Error of } \\
\text { the Estimate }\end{array}$ \\
\hline 1 & $.724^{\mathrm{a}}$ & .523 & .521 & .45421 \\
\hline
\end{tabular}

Linear regression is used to test this hypothesis; it is found that $\mathrm{R}(0.724)$ is the correlation between knowledge implementation and customer experience management. And knowledge sharing was found to clarify $52.3 \%$ of the variance in the customer experience management.

Table 19. ANOVA ${ }^{\text {a }}$ table for $\mathrm{HO-5}$

\begin{tabular}{|c|c|c|c|c|c|}
\hline Model & $\begin{array}{c}\text { Sum of } \\
\text { Squares }\end{array}$ & df & $\begin{array}{c}\text { Mean } \\
\text { Square }\end{array}$ & $\mathbf{F}$ & Sig. \\
\hline Regression & 38.530 & 1 & 38.530 & 186.757 & $.000^{\mathrm{b}}$ \\
\hline $1 \quad$ Residual & 35.073 & 170 & .206 & & \\
\hline Total & 73.602 & 171 & & & \\
\hline
\end{tabular}

Table 20. Coefficients ${ }^{\text {a }}$ table for $\mathrm{H0-5}$

\begin{tabular}{|c|c|c|c|c|c|}
\hline Model & \multicolumn{2}{|c|}{$\begin{array}{c}\text { Unstandardized } \\
\text { Coefficients }\end{array}$} & $\begin{array}{c}\text { Standardized } \\
\text { Coefficients }\end{array}$ & \multirow{2}{*}{ Sig. } \\
\cline { 2 - 4 } & $\mathbf{B}$ & Std. & Beta & & \\
\hline 1Constant) & 1.659 & .150 & & 11.049 & .000 \\
$1 \begin{array}{c}\text { Knowledge } \\
\text { Implementatio }\end{array}$ & .561 & .041 & .724 & 13.666 & .000 \\
\hline
\end{tabular}

Also it is found that the F value of (186.757) is significant at (0.05) level. Thus, there is a statistically significant influence of knowledge implementation on customer experience management in private hospitals in Amman, Jordan

\section{RESULTS AND CONCLUSIONS}

The results of statistical analysis show that the variable with the highest impact on customer experience management is knowledge sharing followed by knowledge storing and knowledge creation (at the same level approximately). This is followed by knowledge acquisition and knowledge implementation, being the least impactful. In general, the descriptive statistical analysis results of the questionnaire, shown in appendix (A), reveal a high tendency by private hospitals towards using the most up-to-date technologies of databases, networks and computer-based knowledge management technologies.

Also one of the interesting findings of the study is that private hospitals in general are aware of the importance of its knowledge management. This is reflected in their keenness to encourage their employees to interact with each other through non-official meetings. Many studies reveal that employees obtain many of their information and knowledge through such meetings. The outcomes also refer to the teamwork culture among employees and how private hospitals support this culture with the purpose of exchanging experiences and solving problems they face at work. Private hospitals in Amman also hold scientific conferences, training courses and workshops to raise the level of their staff and document all such events for future benefit. They also produce periodicals and newsletters to publish their news and achievements among employees and clients. Furthermore, one of the encouraging results of this study is the level of keenness of private hospitals to maintain their qualified and experienced staff to preserve their knowledge capital and utilise it to improve work processes and procedures and enhance clients' services.

However, the results revealed a deficiency in the area of training staff on using databases in a way that maintains the privacy and confidentiality of information ethically. The hospitals should also follow up on their staff to ensure that they apply the knowledge they obtained through the above activities. Generally, the results were in line with the direction in which private hospitals in Jordan are moving, the direction of excellence. This means that there is still room for improvement in performance especially that the outcomes show a high level of impact of KMPs on customer experience management.

\section{RECOMMENDATIONS}

The current study recommends establishing a specialised department concerned with managing knowledge processes in an organised and informed manner in private hospitals. The tasks of this department need to include carrying out research and studies and support KMPs. In addition, the study recommends holding workshops on information security and privacy to acquaint workers with the concept of data and information security and its legal and ethical aspects that are related to misuse of data sources in the hospital. Lastly, the study further advices directing, encouraging and supporting workers in implementing the knowledge they gained, which benefits employees and the work environment in the hospital. 


\section{REFERENCES}

[1] Jordan Ministry of Health official website. 2019, March 10. Retrieved from http://www.moh.gov.jo/default.aspx

[2] High Health Council 2016, February 20. '2016-2020 Jordan National Strategy for the Health Sector' report, issued by the High Health Council (HHC). Retrieved from http://www.hhc.gov.jo/uploadedimages/8f70aacece1e-4762-9e86-4f3d75219beb.pdf

[3] Gao, F., Li, M., and Nakamori, Y. 2003. Critical systems thinking as a way to manage knowledge. Systems Research and Behavioral Science, 20(1), 3-19.

[4] Bergeron, B. 2003. Essentials of knowledge management. Hoboken, New Jersey: John Wiley \& Sons, Inc.

[5] Sujatha, R. and Krishnaveni, R. 2018. Knowledge creating ba as a determinant of work performance of employees: An empirical analysis among pump manufacturing firms in South India. Asia Pacific Management Review, 23(1), 45-52.

[6] Wahba, M. 2015. The impact of organizational structure on knowledge management processes in Egyptian context. The Journal of Developing Areas, 49(3), 275292.

[7] Liebowitz, J. 1999. Knowledge management handbook. London: CRC Press.

[8] Du, R., Ai, S., and Ren, Y. 2007. Relationship between knowledge sharing and performance: A survey in Xi' an, China. Expert Systems with Applications, 32(1), 38-46.

[9] Fong, P. S.W., and Choi, S. K.Y. 2009. The process of knowledge management in professional services firms in the construction industry: a critical assessment of both theory and practice. Journal of Knowledge Management, 13(2), 110-126.

[10] Gholami, M. H., Asli, M. N., Shirkouhi, S. N., and Noruzy, A. 2013. Investigating the influence of knowledge management practices on organizational performance: An empirical study. Acta Polytechnica Hungarica, 10(2), 205-216.

[11] Nonaka, I., Umemoto, K., and Senoo, D. 1996. From information processing to knowledge creation: A paradigm shift in business management. Technology in Society, 18(2), 203-218.

[12] Kaba, A., and Ramaiah, C. K. 2018. Investigating knowledge acquisition among faculty members. Interdisciplinary Journal of Information, Knowledge, and Management, 13, 1-20.

[13] Talet. A.N. 2012. KM process and CRM to manage customer knowledge relationship management. International Conference on Economics, Business and Marketing Management, International Proceedings of Economics Development and Research, 29, 60-67.

[14] Lathalavanya, B. and Thenmozhi R. 2011. Organizational citizenship behaviour evaluating organizational efficiency and success through knowledge sharing. The Journal Contemporary Management Research, 5(1), 24-29.
[15] Lin, H. F. 2007. Knowledge sharing and firm innovation capability: An empirical study. International Journal of Manpower, 28(3/4), 315- 332.

[16] Bock, G.W. and Kim, Y.G. 2002. Breaking the myths of rewards: An exploratory study of attitudes about knowledge sharing. Information Resources Management Journal, 15 (2), 14-21.

[17] Dawson, R. 2001. Knowledge capabilities as the focus of organizational development and strategy. Journal of Knowledge Management, 4 (4), 320-327.

[18] Seligman, J. 2018. Customer Experience Management "The Experiential Journey", lulu.com.

[19] Hashem, T. N., Al-Aqra, S. S., and Haikal, E. K. 2017. Marketing managers' degrees of awareness about the significance of the customer experience management (CEM) in the Jordanian banking, insurance and financia services sectors. Global Journal of Management and Business Research, 17(1), 22-32.

[20] Verhoef, PC., Lemon, KN., Parasuraman, A., Roggeveen, A., Tsiros, M., and Schlesinger, LA. 2009. Customer experience creation: Determinants, dynamics, and management strategies. Journal of Retailing, 85(1), $31-41$.

[21] Schmitt, B. 1999. Experiential marketing: how to get customers to sense, feel, think, act and relate to your company and brands. Journal of Marketing Management, 15(1-3), 53-67.

[22] Kirkby, J., Wecksell, J., Janowski, W., and Berg, T. 2003. The value of customer experience management Strategic Analysis Report, Gartner Research.

[23] Mithas, S., Krishnan, M. S., and Fornell, C. 2005. Why do customer relationship management applications affect customer satisfaction? Journal of Marketing, 69(4), 201209.

[24] Vassit, 2018, March 15. Introduction to customer journey mapping. Retrieved from http://content.vassit.co.uk/intro-to-customer-journeymapping

[25] Malhotra, Y. 1998, 'Knowledge Management, Knowledge Organizations and Knowledge Workers: A View from the Front Lines, 'Maeil Business Newspaper, Online, Retrieved 5/1/2019, http://www.brint.com/interview/maeil.htm.

\section{APPENDIX A}

Study Model Survey Questions Descriptive Statistics

\begin{tabular}{|c|c|c|}
\hline Study Variables & Mean & $\begin{array}{c}\text { Std. } \\
\text { Deviation }\end{array}$ \\
\hline \multicolumn{2}{|c|}{ Knowledge Creation } \\
\hline $\begin{array}{c}\text { The organisation encourages its staff } \\
\text { to learn from the experiences of other } \\
\text { organisations in order to obtain } \\
\text { knowledge. }\end{array}$ & 3.85 & 1.208 \\
\hline $\begin{array}{c}\text { The organisation's staffs interact } \\
\text { with each other to find suitable } \\
\text { solutions for problems they face. }\end{array}$ & 3.66 & 1.360 \\
\hline
\end{tabular}




\begin{tabular}{|c|c|c|}
\hline $\begin{array}{c}\text { The organisation facilitates access to } \\
\text { database for all employees based on } \\
\text { their level of authorisation to help } \\
\text { them achieve their tasks. }\end{array}$ & 3.04 & 1.258 \\
\hline $\begin{array}{c}\text { The organisation regularly informs } \\
\text { all employees about any new } \\
\text { knowledge concerning its field of } \\
\text { work. }\end{array}$ & 2.90 & 1.368 \\
\hline $\begin{array}{l}\text { The organisation assigns employees } \\
\text { to training courses for the purpose of } \\
\text { increasing their scientific and } \\
\text { technical knowledge. }\end{array}$ & 3.87 & 1.291 \\
\hline \multicolumn{3}{|c|}{ Knowledge Acquisition } \\
\hline $\begin{array}{l}\text { The organisation is keen on } \\
\text { acquiring knowledge from its } \\
\text { internal sources. }\end{array}$ & 4.05 & 1.179 \\
\hline $\begin{array}{l}\text { The organisation encourages its } \\
\text { employees to attend conferences and } \\
\text { workshops to gain knowledge. }\end{array}$ & 3.19 & 1.389 \\
\hline $\begin{array}{l}\text { The organisation has a specialised } \\
\text { studies and research department. }\end{array}$ & 2.81 & 1.355 \\
\hline $\begin{array}{l}\text { The organisation encourages and } \\
\text { supports workers if they decide to } \\
\text { pursue further studies to expand their } \\
\text { professional knowledge. }\end{array}$ & 3.77 & 1.160 \\
\hline $\begin{array}{l}\text { The organisation is keen on } \\
\text { acquiring knowledge externally from } \\
\text { customers, clients and competitors. }\end{array}$ & 3.44 & 1.276 \\
\hline \multicolumn{3}{|c|}{ Knowledge Storing } \\
\hline $\begin{array}{l}\text { The organisation seeks to maintain } \\
\text { expert and qualified employees to } \\
\text { preserve its knowledge capital. }\end{array}$ & 3.24 & 1.345 \\
\hline $\begin{array}{l}\text { The organisation has advanced } \\
\text { databases and technologies to store } \\
\text { employees' knowledge. }\end{array}$ & 3.90 & 1.071 \\
\hline $\begin{array}{c}\text { The organisation encourages workers } \\
\text { to document their knowledge. }\end{array}$ & 3.94 & 1.251 \\
\hline $\begin{array}{l}\text { Knowledge about customers, clients } \\
\text { and competitors are documented and } \\
\text { stored. }\end{array}$ & 3.77 & 1.313 \\
\hline \multicolumn{3}{|c|}{ Knowledge Sharing } \\
\hline $\begin{array}{c}\text { The organisation has an internal and } \\
\text { external network that enables } \\
\text { knowledge sharing among all parts } \\
\text { of the organisation. }\end{array}$ & 3.34 & 1.146 \\
\hline $\begin{array}{c}\text { The organisation issues different } \\
\text { newsletters and periodicals to share } \\
\text { new information with the staff and } \\
\text { clients. }\end{array}$ & 3.65 & 1.217 \\
\hline $\begin{array}{l}\text { Team work allows me exchange } \\
\text { knowledge with others. }\end{array}$ & 3.9477 & 1.20556 \\
\hline $\begin{array}{c}\text { The organisation encourages holding } \\
\text { non-official meetings among staff to } \\
\text { exchange work-related views. }\end{array}$ & 3.7093 & 1.37960 \\
\hline $\begin{array}{l}\text { Modern communication tools are } \\
\text { used to enable knowledge sharing } \\
\text { among all parts of the organisation. }\end{array}$ & 3.1337 & 1.28856 \\
\hline \multicolumn{3}{|c|}{ Knowledge Implementation } \\
\hline
\end{tabular}

\begin{tabular}{|c|c|c|}
\hline $\begin{array}{l}\text { The organisation encourages workers } \\
\text { to apply the knowledge they acquire } \\
\text { from different sources. }\end{array}$ & 2.9884 & 1.41417 \\
\hline $\begin{array}{c}\text { Using computer technology } \\
\text { facilitates applying my acquired } \\
\text { knowledge. }\end{array}$ & 3.8837 & 1.29704 \\
\hline $\begin{array}{c}\text { The organisation uses its knowledge } \\
\text { capital to improve work procedures } \\
\text { and customer services. }\end{array}$ & 4.1047 & 1.18004 \\
\hline $\begin{array}{c}\text { The organisation's administration } \\
\text { follows up to ensure that workers } \\
\text { apply the work procedures they were } \\
\text { trained on. }\end{array}$ & 3.2558 & 1.41988 \\
\hline \multicolumn{3}{|c|}{ Customer Experience Management } \\
\hline $\begin{array}{l}\text { Marketing employees are trained on } \\
\text { work ethics pertaining to their access } \\
\text { to organisation's database. }\end{array}$ & 2.8488 & 1.38933 \\
\hline $\begin{array}{c}\text { The organisation uses modern } \\
\text { technologies to collect and analyse } \\
\text { customer data to better serve them in } \\
\text { the future. }\end{array}$ & 3.8547 & 1.15816 \\
\hline $\begin{array}{l}\text { The organisation saves the data } \\
\text { related to their customers' service } \\
\text { preferences. }\end{array}$ & 3.5640 & 1.26652 \\
\hline $\begin{array}{l}\text { The organisation gives considerable } \\
\text { attention to having a complete } \\
\text { detailed profile about each customer. }\end{array}$ & 3.3430 & 1.35241 \\
\hline $\begin{array}{c}\text { The organisation utilises the } \\
\text { customer experience management } \\
\text { system when making strategic } \\
\text { decisions. }\end{array}$ & 3.9302 & 1.08999 \\
\hline $\begin{array}{c}\text { The customer experience } \\
\text { management system helps the } \\
\text { organisation make wise decisions by } \\
\text { analysing the feedback of each } \\
\text { potential decision. }\end{array}$ & 4.0000 & 1.24722 \\
\hline $\begin{array}{l}\text { Marketing managers are provided } \\
\text { with information about the } \\
\text { organisation's customers through } \\
\text { periodical reports. }\end{array}$ & 3.8256 & 1.30847 \\
\hline $\begin{array}{l}\text { The customers experience } \\
\text { management system helps the } \\
\text { organisation reach the best solution } \\
\text { for the concerned problem. }\end{array}$ & 3.3837 & 1.18142 \\
\hline $\begin{array}{l}\text { The organisation exerts many efforts } \\
\text { to develop its database that is linked } \\
\text { with the organisation's customer } \\
\text { experience management system. }\end{array}$ & 3.7093 & 1.21748 \\
\hline $\begin{array}{l}\text { The organisation is highly keen on } \\
\text { developing and applying its customer } \\
\text { experience management system in } \\
\text { order to raise the value provided for } \\
\text { customers through its services. }\end{array}$ & 3.9477 & 1.20556 \\
\hline $\begin{array}{l}\text { The organisation aims to provide a } \\
\text { unique customer experience } \\
\text { management system so it stands out } \\
\text { among its market competitors. }\end{array}$ & 3.7965 & 1.35050 \\
\hline
\end{tabular}

